\title{
Trans fatty acid-forming processes in foods: a review
}

\author{
CLAYTON A. MARTIN, MARIA C. MILINSK, JESUÍ V. VISENTAINER, \\ MAKOTO MATSUSHITA and NILSON E. DE-SOUZA \\ Departamento de Química, Universidade Estadual de Maringá, \\ Av. Colombo, 5790, 87020-900 Maringá, PR, Brasil \\ Manuscript received on September 11, 2006; accepted for publication on January 17, 2007; \\ presented by EURÍPEDES MALAVOLTA
}

\begin{abstract}
There is a mounting concern about the intake of foods containing trans fatty acids (TFA) due to their deleterious effects on human health, mainly on the cardiovascular system. In this way, it is important to consider the processes that form TFA in foods, and the alternatives to minimize them. Among the processes that result in the formation of TFA, the hydrogenation of vegetable oils stands out for its impact on the diet of people living in industrialized countries. Other processes such as edible oil refining, meat irradiation, food frying, and biohydrogenation also contribute to increase the daily intake of TFA.
\end{abstract}

Key words: trans fatty acids, partial hydrogenation, deodorization, frying, irradiation, biohydrogenation.

\section{INTRODUCTION}

Fatty acids constitute the main class of lipids in the human diet, being found in nature mainly as glycerol esters that originate triacylglycerols. In the vegetal and animal kingdoms, fatty acids generally have cis unsaturations. In this form, the hydrogens bound to the double bond carbons are on the same side. In another possible configuration, called trans, the hydrogens are bound to unsaturations carbons on opposing sides.

Fatty acids with one or more unsaturations in the trans configuration are called trans fatty acids (TFA). To this class also belong monounsaturated trans fatty acids (MTFA), a group of fatty acids that have only one unsaturation, which is necessarily in the trans form. Polyunsaturated trans fatty acids (PTFA), similarly to their cis counterparts, have two or more unsaturations, either all trans or not (Dutton 1979, Wolff 1992).

The concern with the ratio of intake of foods containing high TFA amounts has grown in the recent years mainly due to the hazardous effects of these lipids on plasma lipoproteins that increase low density lipoprotein (LDL-c) and lipoprotein a(Lp[a]) levels and decrease the levels of high density lipoprotein (HDL-c). This condition contributes to increase the LDL-c/HDL-c ratio, which is considered an important indicator of the risk of development of cardiovascular diseases (Ascherio et al. 1999, Hunter 2005). Additionally, the high consumption of TFA during pregnancy has been associated to effects on intrauterine development (Decsi and Koletzko 1995). It has also been observed a rise in allergic diseases upon the high ingestion of these fatty acids (Weiland et al. 1999). Based on these observations, it is advisable to reduce the amounts of dietary TFA. Thus, it is important to consider the TFA forming-processes in foods as well as the alternatives to minimize them. From this perspective, the aim of this paper is to discuss the production of TFA in vegetal oil refining and hydrogenation, meat irradiation, food frying, and biohydrogenation. 


\section{VEGETABLE OIL HYDROGENATION}

The production of butter substitutes started in Europe in the mid 19th century prompted mainly by the on butter high price. By request of Napoleon Bonaparte, a French chemist, Mege Mouries, produced an acceptable butter substitute in 1869. This product, made up of a fraction of bovine tallow, presented good consistency and melted in the mouth, which contributed to its acceptance in the consumer market. In subsequent years, lard also came to be used in the development of butter substitutes (Ghotra et al. 2002).

In 1897, the French chemists Sabatier and Senderens discovered that the difference in consistency between vegetable oils and butter, and tallow and lard was due to the lower amounts of hydrogen atoms present. This discovery was based on the use of nickel as a catalyst and allowed the development of a process to produce fats from vegetable and marine oils (Gunstone 1998).

The hydrogenation process found its first industrial application in England in 1903 when fats were prepared from sperm whale oil. In 1909, the process was used in the production of tallow substitutes, whose scarcity compromised soap production (Johnson 1998). In the following years, hydrogenated fats and margarines derived from cotton and soy oils started to be produced in Europe and the United States (Shurtleff and Aoyagi 2004).

From the 1930's on, the hydrogenation industry saw an incredible growth resulting from the consumption of margarines and hydrogenated fats during the Second World War (Shurtleff and Aoyagi 2004). However, until 1940, margarine was regarded as an inferior substitute of butter. In 1941, the Food and Drug Administration (FDA) published a report in the United States lending margarine the status of a staple food (Ghotra et al. 2002).

In the late 1950's, researchers from the Northern Regional Research Center (USA) discovered that alphalinoleic acid (18:3 9c,12c,15c) was related to the formation of unpleasant smells when frying food in soy oil. Thus, it was proposed the development of selective hydrogenation as an alternative to decrease the amount of this fatty acid in soybean oil (Gray and Russell 1979). This strategy led to light hydrogenation, a process in which reduced the amount of alpha-linoleic acid to $3 \%$ of total fatty acids in oil, and extended the possibility of producing fats with specific characteristics (Ackman and Mag 1998).

In Brazil, the hydrogenation industry appeared in the 1950's, initially producing hydrogenated fat and hard margarine. From 1970 on, it started to produce soft margarine by mixing hydrogenated fats with different melting points. The improvement of the hydrogenation process by the development of selective hydrogenation made the production of more and more specific fats and their increased use in food production a possibility. This resulted in the almost complete substitution of animal fats in the diet of the Brazilian population (Pelaez-Alvarez et al. 1991).

Hydrogenation is based on the reaction of unsaturated fatty acids of either vegetable or marine oil in the presence of a catalyst, in general nickel. The objective is to increase the oxidative stability of oils by reducing the concentration of more unsaturated fatty acids and changing their physical properties, thus extending their application.

Hydrogenation depends mainly on oil temperature, hydrogen pressure, stirring speed, reaction time, and the catalyst type and concentration. According to the process conditions, hydrogenation is classified as either partial or total and either selective or nonselective (Gray and Russell 1979).

Selectivity is related to the preferential hydrogenation of more unsaturated fatty acids, which results in the lowest formation of saturated fatty acids possible (Nawar 1996). To obtain high selectivity, it is common to use a low hydrogen pressure, moderate stirring speed, and high temperatures. This leads to scarcity of hydrogen on the catalyst surface, which in turn favors the formation of TFA (Ackman and Mag 1998).

The production of high TFA content fats was considered important for many decades by the hydrogenation industry not only to reduce hydrogen consumption, but also and mainly to improve the physical, chemical, and organoleptic characteristics of fats (Weiss 1983, Karabulut et al. 2003). To increase geometric polymerization, many catalysts were treated with $\mathrm{H}_{2} \mathrm{~S}, \mathrm{SO}_{2}, \mathrm{CS}_{2}$, or $\mathrm{CO}$ to decrease the number of hydrogen adsorption sites (Allen 1981, Johnson 1998). 
The relation between catalyst and hydrogenation selectivity started to be extensively studied in the 1960's, leading to the discovery of several catalysts, among which stand out copper, nickel, palladium and platinum (Gray and Russel 1979).

Copper-based catalysts present high selectivity for alpha-linolenic and linoleic acids with little tendency to form TFA. In the 1970's and 1980's, these catalysts were largely used in light hydrogenation. However, due to their low activity and catalytic effect on unsaturated fatty acid oxidation, their use was little stimulated (Ackman and Mag 1998).

As a result, the use of catalysts was practically restricted to nickel due to its good activity, reasonable selectivity, filterability, reusability, smaller influence on unsaturated fatty acid oxidation, and lower cost relative to those of palladium and platinum (Gray and Russel 1979, Okonek et al. 1995). To increase its catalytic activity and make post-hydrogenation removal easier, nickel is generally supported onto silica, aluminum, chrome, or cobalt oxides (Johnson 1998). Although the use of nickel has several advantages, hydrogenation is never totally selective and the production of TFA is rather significant. Furthermore, catalyst reuse decreases selectivity and increases the formation of TFA (Gray and Russel 1979).

In the last decade, development of modified nickel catalysts that allowed carrying the hydrogenation process at lower temperatures without significantly affecting reaction selectivity and with lower TFA formation have permitted to decrease up to $38.6 \%$ the TFA production during the soybean oil hydrogenation when compared to convention catalysts in the production of fats with an iodine value equal to 70 . For canola oil and fats, the TFA contents decreased up to 50.3 and $66.7 \%$ for iodine values of 90 and 60 , respectively.

Catalysts made from noble metals such as platinum and palladium present high catalytic activity, allowing hydrogenation speeds equivalent to those of nickel at low temperatures (Johnson 1998). Although this condition reduced the formation of TFA, the increase in catalytic activity results in the use of lower catalyst concentrations, which requires an improvement of filtration efficiency and thus limits their application (Gray and Russell 1979). Among these catalysts, modified- platinum presented the possibility of carrying out very selective hydrogenation with low formation of TFA (Okonek et al. 1995).

The mechanism of formation of geometric and positional isomers during hydrogenation was proposed by Allen and Kiess (1955) based on the semi-hydrogenation/dehydrogenation sequence (Figure 1) and confirmed by subsequent studies (Allen and Kiess 1956, Allen 1981). The authors state that during hydrogenation, a hydrogen atom can entered any end of the double bond and form a free-radical site, possibly bound to the catalyst. This free radical site is rather unstable and if the catalyst is partially covered by hydrogen, a hydrogen atom neighboring carbon can be eliminated and thus regenerate the double bond or lead to the formation of a positional isomer. As the formation of a free radical site allows free rotation, the double bond formed may present either cis or trans configuration.

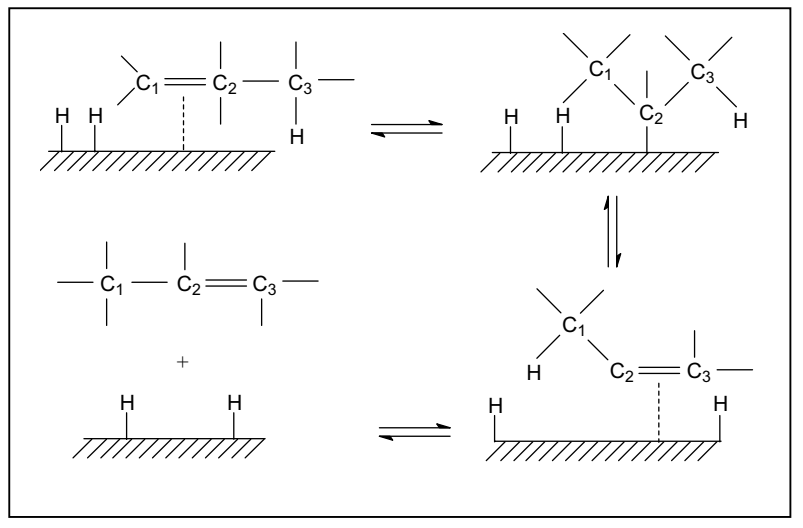

Fig. 1 - Mechanism of formation of geometric and positional isomers in the hydrogenation process (Min 2005).

\section{VEGETABLE OIL REFINING}

A number of substances that can be present in natura vegetable oils may contribute to changes in color, taste, and aroma, restrict their application, and reducing their shelf lifetime. Among these substances free fatty acids, phospholipids, carbohydrates, and proteins as well as their degradation by-products, water, chlorophyll, carotenoids, and fatty acid oxidation products. Therefore, oils are refined to remove these substances. Refining generally includes degumming, neutralization, bleaching, and deodorization steps (Nawar 1996). 
In refining, vegetable oils are commonly heated between 60 and $100^{\circ} \mathrm{C}$ before deodorization. In the sequence, during the deodorization step, which aims to improve oil organoleptic characteristics by removing oil solvent used in the extraction process and low molecular weight compounds, the temperature is increased to 180-270 C (Johnson 1998).

In the determination of the relative amounts of TFA in sunflower raw oil and after degumming, neutralization, bleaching, and deodorization, Tasan and Demirci (2003) observed that the TFA 18:2 content increased 13.8-fold at the end of refining process. Yet, when the deodorization step was carried out at $230^{\circ} \mathrm{C}$ for 2 hours it was responsible for $91.3 \%$ of the TFA production, and when this process was conducted at $265^{\circ} \mathrm{C}$ for 1 hour the increasing in TFA 18:2 content was 57.8-fold in relation to that of raw oil, totaling an increase of $97.4 \%$ in the TFA production.

Wolff (1993) studied the deodorization of flaxseed oil in laboratory scale as a model to evaluate the effect of heating time and temperature on the isomerization of linoleic and alpha-linolenic acids present in refined vegetable oils. This study demonstrated that the formation of TFA 18:2 and 18:3 strongly dependent on these variables and that it starts around $190^{\circ} \mathrm{C}$.

Hénon et al. (1999) studied the isomerization kinetics of linoleic and alpha-linolenic acids during the deodorization of canola oil in laboratory scale and observed the existence of a critical temperature over which isomerization was pronounced. For alpha-linolenic acid, this temperature was in the range $220-230^{\circ} \mathrm{C}$ and for linoleic acid it was higher than $240^{\circ} \mathrm{C}$. As a result, after 4-hour deodorization at $270^{\circ} \mathrm{C}$, about $80 \%$ of the alphalinolenic acid was isomerized, while only $13 \%$ of the linoleic acid produced TFA.

Even though TFAs 18:1, 18:2, and 18:3 are found in cold press vegetable oils, their contents are very low, being generally between 0.1 and $0.3 \%$ of the total fatty acids (Bruhl 1996). The contents of TFA 18:2 and 18:3 normally predominate, but to Bruhl's surprise, some sunflower, safflower, and flaxseed oils, produced in Germany, presented contents of TFA 18:1 as high as 900\%, $488 \%$, and $139 \%$, respectively, of the total of TFA. In this study, it was observed the predominance of TFA 18:1 in relation to PTFA in industrially dried rapeseeds.
According to Ackman and Mag (1998), the use of severe seed drying conditions can be related to the formation of TFA 18:1 through the action of enzymes such as lipoxygenase and dihydroperoxidase. Thus, the formation of TFA in these vegetable systems is possibly much dependent on the temperature.

\section{FOOD FRYING}

Frying is one of the oldest food preparation methods. Its invention is attributed to the Chinese (Rossell 2001). In this process, heat is transferred from oil to foods with resulting food water evaporation and oil absorption (Warner 1998). Several physical and chemical changes also occur in the oil as a result of oxidation, pyrolysis, polymerization, hydrolysis, and isomerization reactions, producing numberless substances that are incorporated into foods and that alter their appearance, aroma, and taste (Moreno et al. 1999, Gertz 2001).

The formation of TFA during food frying is closely related to the process temperature and oil use time (Moreno et al. 1999, Sanibal and Mancini-Filho 2004). When partially hydrogenated fats are used, the formation of TFA is generally lower. However, the high initial contents of these acids result in a larger concentration of trans isomers in fried food (Aro et al. 1998, Romero et al. 2000).

Moreno et al. (1999) evaluated the effects of temperature and time on the formation of trans isomers during sunflower oil heating in an open container. In this study, it was observed that trans unsaturations started to increase at $150^{\circ} \mathrm{C}$ and became much more significant from $250^{\circ} \mathrm{C}$ on. After heating for 20 minutes at 200,250 , and $300^{\circ} \mathrm{C}$, increasing of $356.5 \%, 773.9 \%$, and $3026.1 \%$, respectively, in the concentration of trans isomers in relation to the initial values $(0.22 \mathrm{mg} / \mathrm{g})$ were observed.

Several European countries have determined that the frying oil temperature must not exceed $180^{\circ} \mathrm{C}$. In France, it has been established that the oil commercially used in frying must contain $3 \%$ alpha-linolenic acid at most (Fox 2001, Wolff 2002). These measures not only contribute to decreased degradation of unsaturated fatty acids but also result in a lower formation of MTFA and PTFA during frying.

In a study on the formation of TFA during potato 
frying in soybean oil at around $180^{\circ} \mathrm{C}$ with oil filtering and reposition every 10 hours, Sanibal and ManciniFilho (2004) observed a significant increase in MTFA in oil with increasing heating time. A larger content of PTFA group after 10-hour frying corresponding to an increase of $55.2 \%$ relative to the amount initially present in oil $(2.1 \%)$ was observed. The linear regression analysis of the results obtained by for MTFA (Figure 2) demonstrated that the formation of these isomers was linearly dependent on frying time, with an isomerization ratio of about $0.3 \%$ per hour relative to the total fatty acids in oil.

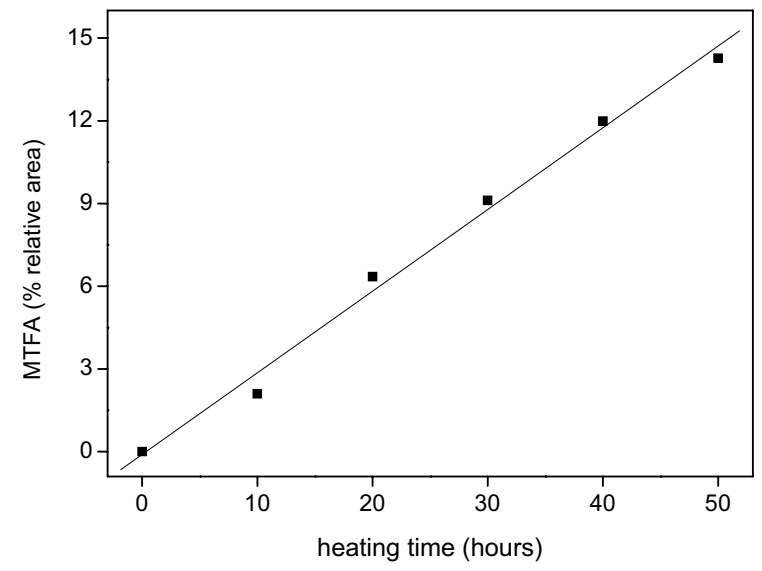

Fig. 2 - MTFA contents as a function of soy oil heating time (obtained from data determined by Sanibal and Mancini-Filho (2004); $r=0.996$; $\mathrm{p}<0.0001 ; \mathrm{y}=-0.110+0.297 \mathrm{x})$.

\section{FOOD IRRADIATION}

The use of irradiation technology in food preservation has raised large interest mainly due to its efficiency and its multiple possibilities of application. Irradiation of meats increases their shelf lifetime by protecting them from pathogenic microorganism. However, irradiation produces structural changes in many nutrients, which may have important consequences on the nutritional value of foods (Nawar 1996).

The free radicals formed by irradiation of unsaturated fatty acids react with oxygen and lead to the formation of carbonyl compounds, which are responsible for associated changes in nutritional and organoleptic characteristics of foods. Furthermore, breaking the double bond favors the formation of TFA as its regeneration in the trans configuration reduces the free energy of the fatty acid (Allinger et al. 1978).

Many controversies on appropriate doses for food irradiation remain. For the red meat group, countries such as the United States and Canada have established that irradiation of fresh food must not exceed $4.5 \mathrm{kGy}$. Nevertheless, in England, it is doses of up to $7.0 \mathrm{kGy}$, while in South Africa meats are irradiated with $45 \mathrm{kGy}$ (IFST 1998, FDR 2002).

Brito et al. (2002) evaluated the effect of increasing gamma radiation doses on TFA content in fresh bovine meat following to irradiation. They observed that doses between 1-5 kGy were associated to an average increase of $80.4 \%$ in the amount of TFA. Doses between 6 and $7 \mathrm{kGy}$ led to an increase of $106.5 \%$ in TFA content. At $8 \mathrm{kGy}$, it reached $139.1 \%$, corresponding to $11.0 \%$ of the total fatty acids. Thus, irradiation with doses between 1 and $5 \mathrm{kGy}$ seem to be the most indicated to limit TFA formation.

\section{BIOHYDROGENATION}

In animals belonging to the Ruminantia suborder, the action of microorganisms present in the rumen such as Butyrivibrio fibrisolvens and Megasphaera esdenii leads to the isomerization of polyunsaturated fatty acids, resulting in 18:2 $9 c, 11 t$ and 18:2 10t,12c, from linoleic acid (Figure 3). These fatty acids, called conjugated linoleic acid (CLA), can be absorbed by the animal or be biohydrogenated to form acids 18:1 11t (vaccenic acid) and 18:1 10t, which can also be obtained from alpha and gamma linolenic acids. Next, these MTFA can be either absorbed or hydrogenated to form stearic acid (18:0). When absorbed, these acids are incorporated in the adipose and muscle tissues of the animal. Acid 18:2 $9 c, 11 t$ can be formed from vaccenic acid through the action of enzyme delta-9-desaturase (Bauman et al. 1999, Khanal and Dhiman 2004).

The effects observed for acids 18:2 $9 c, 11 t$ and 18:2 $10 t, 12 c$ are distinct from those of other TFA. Isomer $9 c, 11 t$ seems to have physiological importance as an antioxidant and in the inhibition of several forms of neoplasias as demonstrated in animal studies (Visonneau et al. 1997). The effect observed for the isomer 18:2 $10 t, 12 c$ on the metabolism of lipids is important as this acid is capable of generating favorable body composition changes in some people (Kelly 2001). 


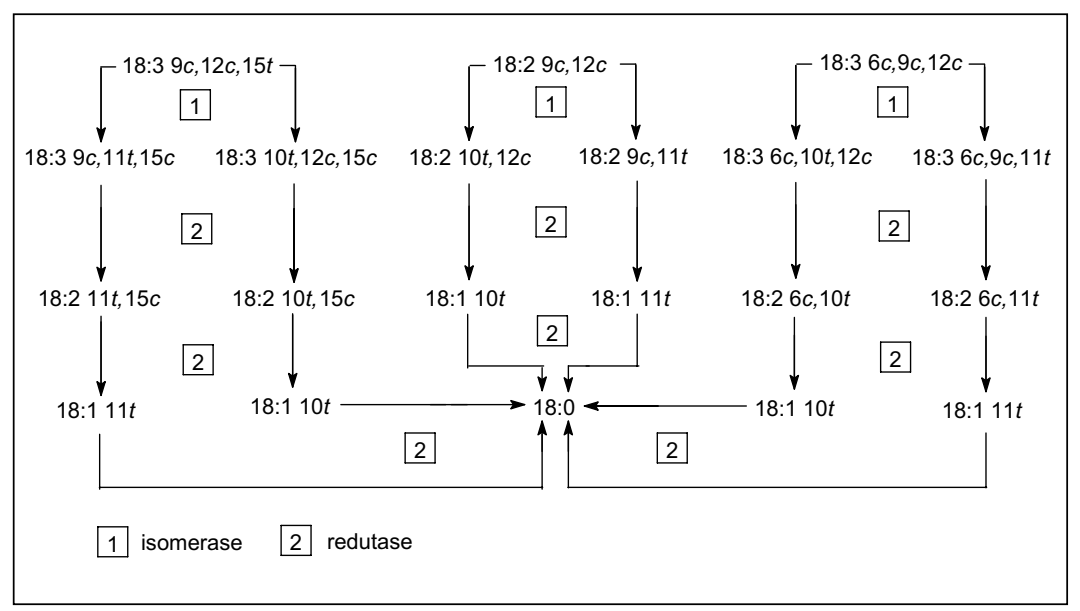

Fig. 3 - Formation of acids 18:1 $11 t$ and 18:1 $10 t$ in ruminants from linoleic, alphalinolenic, and gamma-linolenic acids (adapted from Khanal and Dhiman 2004).

Studies carried out with bovines have demonstrated that diets with low fiber content lead to an increase in acid 18:1 $10 t$ and a decrease in 18:1 $11 t$ in milk due to low rumen $\mathrm{pH}$ as a result of changes in the fermentative process (Bauman et al. 1999). It has also been observed that a decrease in the vaccenic acid concentration in milk under restricted fiber diet correlates directly with the concentration of CLA and inversely with an increase in 18:1 10t.

Oleic acid $(18: 19 c)$ is converted into estearic acid by biohydrogenation. However, it has also been observed that microorganisms present in the rumen form acid 18:1t with unsaturations distributed from carbons 6 to 16 as demonstrated by Mosley et al. (2002) during the in vitro study of bovine rumen tissue. Furthermore, when canola oil with high oleic acid content (78\%) was added to the cow diets (Jenkins 2000) it was observed an increase of $145 \%$ in TFA 18:1 in the animal milk in relation to that of animals fed a control diet without oil addition.

\section{FINAL CONSIDERATIONS}

The production of fats through hydrogenation has been directed to reduce TFA contents. For such, process conditions have been modified and hydrogenation has been combined to chemical interesterification. As a consequence of this effort, as already observed in other coun- tries, the dietary intake of TFA by the Brazilian population will decrease significantly in the future years.

The use of high temperatures in vegetal oil deodorization is an important factor for increased dietary PTFA intake and consequently to reduce the daily intake of alpha-linolenic acid (18:3n-3). However, this situation can be easily changed with the use of temperatures lower than $200^{\circ} \mathrm{C}$ in this refining step.

The preference for the use of hydrogenated fats in food frying has been observed. Although the production of these fats is geared to minimize the formation of TFA, high temperatures for long times can result in a considerable increase in TFA content, and consequently, in a larger transference to foods, similarly to that observed for vegetal oil frying. Thus, it is necessary to carry out studies to establish temperature and use time limits for frying oils and fats.

With the growing interest in improving meat quality, the use of irradiation will become far more common in the next decades. Thus, meat consumption, mainly of ruminants, will have a significant impact on dietary TFA levels.

Due to the favorable effects of CLA on the human organism, the diets of ruminants have been manipulated to maximize the production of these fatty acids during biodegradation. This will contribute to an increase in daily CLA intake and influence the amounts of vaccenic acid in people's diets. 


\section{RESUMO}

Existe uma crescente preocupação em relação a ingestão elevada de ácidos graxos trans (AGT), devido aos seus efeitos desfavoráveis à saúde, principalmente sobre o sistema cardiovascular. Assim, é importante considerar os processos que originam os AGT nos alimentos, e as alternativas para minimizar a sua formação. Entre os processos que resultam na produção de AGT, a hidrogenação de óleos vegetais tem recebido o maior destaque por seu impacto na dieta de pessoas que vivem em países industrializados. Outros processos, como o refino de óleos vegetais, a irradiação de carnes, o preparo de alimentos fritos e a bio-hidrogenação, também contribuem para aumentar a ingestão diária de AGT.

Palavras-chave: ácidos graxos trans, hidrogenação parcial, desodorização, fritura, irradiação, bio-hidrogenação.

\section{REFERENCES}

ACKMAN RG AND MAG TK. 1998. Trans fatty acids and the potential for less in technical products. In: SÉBÉDIO JL AND CHRISTIE WW (Eds), Trans fatty acids in human nutrition. Dundee: The oil press.

ALlen RR. 1981. Hydrogenation. J Am Oil Chem Soc 58: 166-169.

ALLEN RR AND KIESS AA. 1955. Isomerization during hydrogenation. I. Oleic acid. J Am Oil Chem Soc 32: 400-405.

ALLEN RR AND KIESS AA. 1956. Isomerization during hydrogenation. III. Linoleic acid. J Am Oil Chem Soc 33: $355-400$.

Allinger NL, CAVA MP, De Jongh DC, Johnson CR, Lebel NA AND STEVEns CL. 1978. Química Orgânica, $2^{\text {nd }}$ ed., Rio de Janeiro: Ed Guanabara Koogan, 951p.

Aro A, Amaral E, Kesteloot H, Rimestad A And THAMM VAN POPPEL G. 1998. Trans fatty acids in french fries, soups, and snacks from 14 european countries: The TRANSFAIR study. J Food Comp Anal 11: 170-177.

Ascherio A, KatAN MB, Zock PL, StAmpfer MJ AND WILLETT WC. 1999. Trans fatty acids and coronary heart disease. New England J Med 340: 1994-1998.

BAUMAN DE, BAUMgard LH, CORL BA AND GRIINARI JM. 1999. Biosynthesis of conjugated acid in ruminants. Proceedings of the American Society Animal Science, 1999. Retrieved nov 01, 2005 from homepage: http://www.asas.org/jas/symposia/proceedings/0937.pdf.

BRITO MS, VILlAVICENCIO ALCH AND MANCINI-FILHO
J. 2002. Effects of irradiation on trans fatty acids formation in ground beef. Radiation Physics and Chemistry 63: 337-340.

BRUHL L. 1996. Determination of trans fatty acids in cold pressed oils and dried seeds. Fett/Lipid 98: 380-383.

Decsi T And Koletzko B. 1995. Do trans fatty acids impair linoleic acid metabolism in children? An Nutr Met 39: $36-41$.

DUTTON HJ. 1979. Hydrogenation of fats and its significance. In: ERAKen EA AND DUtTon HJ (Eds), Geometrical and positional isomers. Champaign, IL: American Oil Chemists Society.

FDR - FoOD AND DRUg Regulations. 2002. Regulations Amending the food and drugs regulations (1094Food Irradiation). Canada Gazette, v. 136, n. 47, 23 nov. 2002. Retrieved nov 08, 2005 from home page: http://canadagazette.gc.ca/partl/2002/20021123/html/ regte1-e.html.

Fox R. 2001. Regulation in the European Union. In: RosSELL JB (Ed), Frying: improvement quality. New York: CRC Press.

Gertz C. 2001. Preface. In: Rossell JB (Ed), Frying: improvement quality. New York: CRC Press.

GHOTRA BS, DYAL SD AND NARINE SS. 2002. Lipid shortenings: a review. Food Res Inter 35: 1015-1048.

GRAY JI AND RUSSELL LF. 1979. Hydrogenation catalysts their effect on selectivity. J Am Oil Chem Soc 56: 36-56.

GUNSTONE FD. 1998. Movements towards tailor-made fats. Progr. Lipid Res 37: 277-305.

Hénon G, Kemény Z, Recseg K, Zwobada F and Kovari K. 1999. Deodorization of vegetable oils. Part I: Modeling the geometrical isomerization of polyunsaturated fatty acids. J Am Oil Chem Soc 76: 73-81, 1996.

HUNTER JE. 2005. Dietary levels of trans fatty acids: basis for health concerns and industry efforts to limit use. Nutr Res 25: 499-513.

IFST - Institute of Food SCIENCE AND TeCNOLOGY. 1998. The use of irradiation for food quality and safety. Retrieved nov 08, 2005 from home page: http://www.ifst.org/hottop11.htm.

JEnkins TC. 2000. Feesing oleamide to lactating Jersew cows 1. Effects on lactation performance and milk fatty acid composition. J Dairy Sci 83: 332-337.

JOHNSON LA. 1998. Recovery, refining, converting, and stabilizing edible fats and oils. In: Акон CC AND MIN DB (Eds), Food Lipids. New York: Marcel Dekker. 
KARABUlut I, KaYAhan M AND YAPRAK S. 2003. Determination of changes in some physical and chemical properties of soybean oil during hydrogenation. Food Chem 81: 453-456.

KeLLY CG. 2001. Conjugated linoleic acid: a review. Altern Med Rev 6: 367-382.

Khanal RC AND Dhiman TR. 2004. Biosynthesis of conjugated linoleic acid (CLA): a review. Pak J Nutr 3: 72-81.

MIN DB. 2005. Food Lipids. Retrieved nov 10, 2005 from home page: http://class.fst.ohio-state.edu/fst821.

Moreno MCMM, Olivares DM, López FJA, AdelanTADO JVG AND REIG FB. 1999. Determination of unsaturation grade and trans isomers generated during thermal oxidation of edible oils and fats by FTIR. J Molec Struct 482: 551-556.

Mosley Ee, Powell GL, Riley MB and Jenkins TC. 2002. Microbial biohydrogenation of oleic acid to trans isomers in vitro. J Lipid Res 43: 290-296.

NAWAR WW. 1996. Lipids. In: Fenema OR (Ed), Food Chemistry. New York: Marcel Dekker.

OKoneK DV, Berben PH And Martelli G. 1995. Precious metal catalysis for fats and oils applications. In: LATIN AMERICAN CONGRESS AND EXHIBIT ON FATS AND OILs Processing, 6, Campinas. Proceedings. Campinas: Sociedade Brasileira de Óleos e Gorduras, p. 39-46.

Pelaez-Alvarez VM, SZMrecsányi T AND TANGo JS. 1991. Determinants of Technological Innovation in the Shortening Industry. In: International MeEting on Fats AND OILS, 1, Campinas. Proceedings. Campinas: Sociedade Brasileira de Óleos e Gorduras, p. 129137.

Romero A, Cuesta C And SÁnchez-Muniz FJ. 2000. Trans fatty acid production in deep fat frying of frozen foods with different oils and frying modalities. Nutr Res 20: 599-608.
Rossell JB. 2001. Introduction. In: Rossell JB (Ed), Frying: improvement quality. New York: CRC Press.

Sanibal EAA and Mancini-Filho J. 2004. Perfil de ácidos graxos trans de óleo e gordura hidrogenada de soja no processo de fritura. Ci Tecnol Alim 24: 27-31.

Shurtleff W and Aoyagi A. 2004. History of soy oil hydrogenation and of research on the safety of hydrogenated vegetable oils. Retrieved nov 08, 2005 from home page: http://www.thesoydailyclub.com/SFC/ MSP products501.asp.

TASAN M AND DEMIRCI M. 2003. Trans FA in sunflower oilat at different steps of refining. J Am Oil Chem Soc 80: $825-828$

Visonneau S, Cesno A, Tepper SA, Scimeca JA, SANTOLI D AND KRISTSChEVSKY D. 1997. Conjugated linoleic acid supresses the growth of human brest adenocarcinoma cells in SCID mice. Anticancer Res 17: 969-974.

WARNER K. 1998. Chemistry of frying fats. In: AKOH CC AND Min DB (Eds), Food Lipids. New York: Marcel Dekker.

Weiland SK, Von Mutius E, Husing A And Asher MI. 1999. Intake of trans fatty acids and prevalence of childhood asthma and allergies in Europe. Lancet 353: 2040-2041.

WeIsS T. 1983. Food oils and their uses. Connecticut: The AVI Publishing Company INC.

WOLFF RL. 1992. Trans polyunsaturated fatty acids in French edible rapeseed and soybean oils. J Am Oil Chem Soc 69: 106-110.

WOLFF RL. 1993. Further studies on artificial geometrical isomers of alpha-linolenic acid in edible acid-containing oils. J Am Oil Chem Soc 70: 219-224.

WOLFF RL. 2002. Are trans isomers of alpha-linolenic acid of nutritional significance for certain populations? Lipids 37: $1147-1148$. 